\title{
Kategorija »ekscentrične pozicionalnosti« u teološkoj perspektivi - Wolfhart Pannenberg i Helmuth Plessner
}

Ivo Džinić*

idzinic@hrstud.hr

\author{
https://doi.org/10.31192/np.17.3.1 \\ UDK: 141.319 .8 \\ 2Pannenberg, W. \\ 1Plessner, $\mathrm{H}$. \\ Izvorni znanstveni rad / Original scientific paper \\ Primljeno: 3. lipnja 2019. \\ Prihvaćeno: 30. rujna 2019.
}

U članku se obrađuje pokušaj razumijevanja čovjeka karakterističan za filozofsku antropologiju s početka 20. stoljeća. U tom kontekstu se na poseban način osvrće na kategoriju »ekscentrične pozicionalnosti« čovjeka u odnosu na druge oblike svijeta života, kako ju je formulirao Helmuth Plessner, jedan od glavnih predstavnike te svojevrsne podgrane cjelokupne filozofske antropologije. Središnju temu članka čini uvid u teološku interpretaciju Plessnerove kategorije čovjekove ekscentričnosti koju je poduzeo evangelički teolog Wolfhart Pannenberg. Pozitivno vrjednujući i prihvaćajući Plessnerove filozofsko-antropološke izvode, Pannenberg ih je nastojao dalje produbljivati u teološkoj perspektivi, pokušavajući tako pokazati nužnost prihvaćanja religijske dimenzije u karakterističnim i općeprihvaćenim antropološkim fenomenima. U prilogu će se nastojati pokazati i koliko su takve teološke interpretacije poželjne i uopće moguće, te će se ukazati i na neke kritičke opaske na Pannenbergov pokušaj teološkoga pristupa rezultatima jedne strogo filozofske antropologije.

Ključne riječi: antropologija, ekscentričnost, filozofija, otvorenost svijetu, povjerenje, teologija.

\footnotetext{
* Izv. prof. dr. sc. Ivo Džinić, Sveučilište u Zagrebu, Hrvatski studiji, Borongajska cesta 83d, HR10000 Zagreb.
} 


\section{Uvod}

Filozofska antropologija s početka 20. stoljeća, čiji su glavni predstavnici bili Max Scheler (1874-1928), Arnold Gehlen (1904-1976), Helmuth Plessner (1892-1985) i drugi, označavala je zanimljiv pristup filozofskog uvažavanja rezultata bioloških istraživanja u pokušaju razumijevanja i određenja čovjeka kao takvog. Riječ je o specifičnom pristupu čovjeku na temelju principa života te pokušaju da se odredi njegova posebnost u sferi organskoga svijeta. U tom pristupu i pokušaju iznjedrili su se neki pojmovi koji će kasnije postati temeljnima za suvremenu filozofsku antropologiju, poput Schelerove i Gehlenove karakterizacije čovjeka sintagmom otvorenosti svijetu (Weltoffenheit), kao i Plessnerovom interpretacijom te sintagme na sebi vlastit način, te napose uvođenjem kategorije »ekscentrične pozicionalnosti« u razmatranje čovjekova osobitog položaja u svijetu.

Zbog svoje specifičnosti u pogledu razumijevanja čovjeka, iz koje se lako može dalje promišljati i o transcendentalnoj dimenziji čovjeka, posebno se čini zanimljivim upravo Plessnerov pokušaj određenja čovjeka kategorijom ekscentričnosti. Stoga i ne čudi što je među pojedinim teolozima bilo pokušaja recepcije takvog razumijevanja čovjekove specifičnosti kao i potrebe za njegovim daljnjim propitivanjem $\mathrm{s}$ teološkog motrišta. Jedan od najznačajnijih u tom pogledu svakako je bio njemački evangelički teolog Wolfhart Pannenberg (1928-2014), ${ }^{1}$ koji je na temelju izvoda netom spomenutog pokušaja filozofske antropologije općenito, i unutar nje posebice Plessnerovih misaonih dosega, nastojao ići korak dalje u pravcu teološke interpretacije čovjekove ekscentrične pozicionalnosti u svijetu. U ovom članku će se nastojati prikazati taj Pannenbergov zanimljiv pokušaj vrednovanja rezultata filozofske antropologije te njihova izazova i prihvatljivosti za teološku interpretaciju.

\section{Specifičnost Pannenbergova pristupa filozofskoj antropologiji}

Wolfhart Pannenberg se je u svojoj teološkoj misli možda i najodvažnije upustio u raspravu s drugim, neteološkim znanostima, i to ne samo humani-

\footnotetext{
${ }^{1}$ Wolfahrt Pannenberg je jedan od najpoznatijih suvremenih evangeličkih teologa. Predavao je sustavnu teologiju na teološkim učilištima u Wuppertalu i Mainzu, a potom do umirovljenja i u Münchenu, gdje je utemeljio i Institut za fundamentalnu teologiju i ekumenu radi unaprjeđenja dijaloga s Rimokatoličkom crkvom. Iako je njegova teološka misao općeprihvaćena na međunarodnoj razini, u Hrvatskoj je Pannenbergova recepcija, nažalost, gotovo beznačajna. Ovdje tek naznaka o dvije vrlo korisne bibliografske jedinice: Hrvoje ŠPEHAR, Wolfhart Pannenberg, u: Ratimir VINCE (ur.), Kršćanska misao XX. stoljeća, Zagreb, Hrvatski radio - Kršćanska sadašnjost, 2009, 577-582; Ivan KEŠINA, Teologija u dijalogu s prirodnim znanostima, u: Pero ARAČIĆ (ur.), Teologija u dijalogu s drugim znanostima. Radovi znanstvenog simpozija s međunarodnim sudjelovanjem o 200. obljetnici filozofsko-teološkog studija u Đakovu, 1806.-2006., Đakovo, Katolički bogoslovni fakultet u Đakovu, 2008, 19-50.
} 
stičkim nego i prirodnim i društvenim znanostima. Kao osoba koja je znala povezati dimenziju vjere s velikim filozofskim obrazovanjem, smatrao je da se akademska teologija jednostavno mora upustiti u probleme aktualne povijesne svijesti, ako želi suvremenom svijetu na razumljiv način posredovati istine vjere. ${ }^{2}$ Time je Pannenberg nastojao humanističkim, ali i drugim znanostima, ponuditi teološku perspektivu, te pokazati da je i teologija otvorena za sudjelovanje u suvremenoj znanstvenoj interdisciplinarnosti.

U teološkoj misli Pannenberg se neprestance bavio nominalnim određenjem Boga kao onoga koji utječe na cjelokupnu zbilju. ${ }^{3}$ Polazeći od takvog teološkog pristupa Pannenberg smatra da je ne samo moguće nego i potrebno kritičko uvažavanje rezultata drugih znanosti za teološku misao. Sasvim konkretno je to nastojao pokazati teološkom interpretacijom samih antropoloških fenomena kao produkta dostignuća filozofske antropologije s početka 20. stoljeća. Takvim pristupom je Pannenberg htio razriješiti i problem suvremenog utemeljenja teološkoga diskursa, ističući da je kršćanskoj teologiji u kontekstu suvremenog osporavanja kršćanske vjere nemoguće sačuvati istinu govora o Bogu bez čvrstog zahtjeva za općom valjanošću, pa njezina obrana danas mora uslijediti na području interpretacije ljudske egzistencije. ${ }^{4}$ I to je jedan od razloga što je Pannenberg otvoren za spoznaje humanističkih znanosti i što kao teolog kritički vrednuje neteološke antropološke spoznaje.

Za razliku od tradicionalne dogmatske antropologije i njezinog apriornog uvažavanja božanske zbilje, Pannenberg nastoji ponuditi fundamentalno-teološku antropologiju koja ne nastoji dokazivati na temelju dogmatskih činjenica i pretpostavki, nego se radije obraća izravno fenomenima ljudske egzistencije koje su istražile biologija, psihologija, kulturalna antropologija ili sociologija, te propituje rezultate tih disciplina očima dubljega razumijevanja koje bi bilo relevantno za religiju i teologiju. ${ }^{5} \mathrm{U}$ tom smislu i teološko kritičko vrjednovanje dostignuća drugih antropoloških disciplina doista ozbiljno s njima računa, ali samo u okviru polaznog razumijevanja stvarnoga stanja, te uviđajući njihovu nedostatnost $\mathrm{u}$ tom pogledu, ukazuje na potrebu uvođenja jedne filozofski nužne i teološki relevantne dimenzije. Pannenbergova opća pretpostavka jest da fenomeni čovječnosti opisani u antropološkim disciplinama čine »samo prolazno razumijevanje stvarnih stanja« koje treba na taj način produbiti »da na temelju samih antropoloških rezultata treba biti dokazana daljnja teološki relevantna

\footnotetext{
${ }^{2}$ Usp. Friedrich Wilhelm GRAF, Wolfhart Pannenberg (02.10.1928 - 04.09.2014); https://badw. de/fileadmin/nachrufe/Pannenberg\%20Wolfhart.pdf (03.06.2019).

${ }^{3}$ Usp. Magnus STRIET, Verdankte Autonomie. Humanwissenschaften und Schöpfungsglaube, u: Antonio AUTIERO i dr. (ur.), Endliche Autonomie. Interdisziplinäre Perspektiven auf ein theologisch-etisches Programm, Münster, LIT Verlag, 2004, 121-141, 133.

${ }^{4}$ Usp. Wolfhart PANNENBERG, Anthropologie in theologischer Perspektive, Göttingen, Vandenhoeck \& Ruprecht, 1983, 15.

${ }^{5}$ Usp. isto, 21.
} 
dimenzija «. ${ }^{6}$ Pod tom teološki relevantnom dimenzijom dakako da Pannenberg misli na religioznu dimenziju, koju je na temelju samih antropoloških fenomena nastojao prikazati kao konstitutivni element ljudskosti te time, kako je već rečeno, općoj svijesti o naravi čovjeka vratiti njezinu religioznu dimenziju. I u tom smislu Pannenberg donosi pravo osvježenje i ambicioznu odvažnost, jer nastoji pokazati i filozofski obrazložiti da karakteristični i općeprihvaćeni antropološki fenomeni imaju temeljnu religioznu dimenziju. Međutim, za njega to ne znači da je strogo nereligiozna perspektiva o čovjeku pogrješna, nego je nepotpuna i nedostatna, te zaključuje da se čovjekova bit ne može razumjeti bez religiozne konstante. Ljudska narav je, naime, u svojoj biti religiozno određena bez obzira na to što čovjek nije uvijek eksplicitno toga i svjestan. ${ }^{7}$ Polazeći od takvog razumijevanja čovjeka, dakle kao razumskog bića koje je konstitutivno religiozno, Pannenberg je antropološkim argumentima kritizirao i moderno društvo, smatrajući da je nedostatnost vjere istinski promašaj čovjekove biti. ${ }^{8}$

Spomenutim kritičkim vrednovanjem rezultata filozofske antropologije s početka 20. stoljeća Pannenberg u svojem razumijevanju čovjeka polazi od same ljudske strukture kao odmaka od svojeg tijela u svojem tijelu. U središtu njegove antropologije stoji fenomen posebnog čovjekova mjesta unutar evolucije života, koji je kod Maxa Schelera i Arnolda Gehlena obilježen kao otvorenost svijetu (Weltoffenheit), a kod Helmutha Plessnera pojmom ekscentričnosti (Exzentrizität). Tim empirijskim dimenzijama ljudskoga postojanja kao dostignućima filozofske antropologije Pannenberg pristupa filozofski ozbiljno i odlučno, smatrajući da su one kvalitetna platforma i nužnost za daljnje teološko promišljanje o ljudskoj naravi. To naime proizlazi iz nenaturalističkog okvira filozofske antropologije koji se, između ostaloga, očituje i u kritici sheme strogo biheviorističkog objašnjenja ljudskog ponašanja. ${ }^{9}$ Poznato je da je unutar antropološkog područja na početku 19. stoljeća primat među znanostima preuzela biologija sa snažnim uvjerenjem o ovozemaljskoj pripadnosti i samoniklosti čovjeka, a samim tim i uvjerenjem u čvrste temelje antropologije za koje je potrebno samo prikupiti dostatan empirijski materijal. Međutim, poslije se pokazalo da ni brojne empirijske činjenice nisu po sebi dovoljne za razumijevanje čovjeka i njegova života. Štoviše, ubrzo je utvrđeno da je te empirijske činjenice nužno prije svega adekvatno interpretirati, a potom da se i takve interpretacije

\footnotetext{
${ }^{6}$ Isto, 19.

7 Usp. Aron LANGENFELD, Magnus LERCH, Theologische Anthropologie, Paderborn, Ferdinand Schöning, 2018, 78.

${ }^{8}$ Pannenberg je zastupao stajalište da se besmislenost modernog društva i njegovih krhkih institucija, a koja je uvjetovana sekularizacijom, može uspješno nadići samo odlučnim reaktiviranjem kršćanskih temelja društvene zajednice, odnosno obnovom teonomne kulture. Međutim, Pannenberg nigdje ne pojašnjava kako bi ta temeljna promjene kulturne zbilje uopće trebala izgledati (usp. Graf, Wolfhart Pannenberg...).

${ }_{9}^{9}$ Usp. Striet, Verdankte Autonomie..., 135.
} 
uglavnom temelje na stanovitim metafizičkim principima i pretpostavkama. ${ }^{10}$ $\mathrm{Na}$ taj način je upravo filozofska antropologija utvrdila prirodnu nestabilnost ljudskog instinktivnog života, što je očito upućivalo na oblike ponašanja koje nije više moguće pojasniti modelom podražaja i reakcije kakav se prepoznaje $u$ životinjskom svijetu.

Da bi nadoknadio svoje specifične manjkavosti ili nedostatke u odnosu na životinjsku podražajnu strukturu, čovjek je očito bio prisiljen kompenzacijski djelovati, što ga onda i razlikuje od svih drugih životinja. ${ }^{11}$ Naravno da se time izričito ne poriče naravni temelj ljudskoga postojanja i ponašanja, ali se jasno ističe i čovjekova specifičnost nenavezanosti na okoliš i otvorenosti svijetu. ${ }^{12}$ U svojem djelu iz 1962. godine pod nazivom Što je čovjek? Pannenberg se ponajviše referira upravo na karakterizaciju čovjeka kao bića otvorenog svijetu, te upućuje na nužnost čovjekove potpune otvorenosti putem svakog iskustva i svake dane situacije, odnosno na otvorenost prema Bogu..$^{13} \mathrm{U}$ svojim kasnijim antropološkim spisima, napose u svojoj Antropologiji u teološkoj perspektivi, Pannenberg se najviše usredotočio na Plessnerovu karakterizaciju čovjeka kao ekscentrično pozicioniranoga bića.

\section{Teološka interpretacija Plessnerove pozicionalnosti ekscentrične forme}

\subsection{Problem (ne)utemeljenosti teoloških interpretacija}

Proizlazi da je Plessnerova kategorija ekscentrične pozicionalnosti čovjeka unutar svijeta živoga zanimljiv i primamljiv izazov za različite teološke interpretacije. To je razvidno i iz dosadašnjih eksplikacija razložnosti Pannenbergova vrednovanja dosega filozofske antropologije općenito, pa samim tim i Plessnerove kategorije čovjekove ekscentričnosti. Međutim, potrebno je ukazati

\footnotetext{
${ }^{10}$ Usp. Nikola SKLEDAR, Čovjekov opstanak. Uvod u antropologiju, Zagreb, Hrvatsko filozofsko društvo, 1996, 42.

${ }^{11}$ Teoriju o čovjeku kao biću koje je poglavito određeno nedostatcima, odnosno koje je u usporedbi s drugim visokim oblicima života biološki neprilagođeno i morfološki nespecijalizirano biće, te koje taj svoj nedostatak nadoknađuje svojom sposobnošću za djelovanje i inteligencijom kompenzacijski stvarajući kulturu, na poseban je način razvio Arnold Gehlen u svojoj poznatoj antropološkoj studiji Čovjek, njegova priroda i njegov položaj u svijetu, Sarajevo, Veselin Masleša, 1974.

${ }^{12}$ Pojam otvorenosti svijetu (Weltoffenheit) uveo je Max Scheler 1928. godine označivši time čovjeka kao biće koje je, za razliku od životinje i njezine vezanosti uz instinkt, slobodno biće u odnosu na okoliš (umweltfrei), biće koje drukčije od životinje posjeduje mogućnost ovladavanja nagonima (usp. Max SCHELER, Položaj čovjeka u kozmosu, Zagreb, Fabula nova, 2005, 32-33).

${ }^{13}$ Usp. Wolfhart PANNENBERG, Was ist der Mensch? Die Anthropologie der Gegenwart im Lichte der Theologie, Göttingen, Vandenhoeck \& Ruprecht, 1985, 9 i dalje.
} 
na neke poteškoće koje iz toga proizlaze da se ne bi zapalo u puku proizvoljnost te samim tim i besmislenost takvih daljnjih izvoda. $U$ tom smislu je važno istaknuti da je Plessner u svojim različitim antropološkim djelima ${ }^{14}$ pokušao razumjeti čovjeka polazeći od njega samoga, ne shvaćajući ga kao Božje stvorenje niti kao onoga koji bi imao neko svoje poslanje koje može ispuniti ili promašiti. ${ }^{15}$ Pojam ekscentričnosti ukazuje na imanentne uvjete čovjekova života i njegovu emancipiranost u odnosu na religiju.

Sve to i dovodi u poteškoće pokušaje upravo takvoga teološkog interpretiranja njegovih postavki. Međutim Plessner, s druge strane, kao da donekle barem izaziva, ako ne i pospješuje, i takve mogućnosti jer se u svojem pokušaju određenja čovjeka dotiče i religije smatrajući je posljedicom ljudske potrebe zbog vlastite neuravnoteženosti u svijetu i ideje o ništavnosti svijeta. Ekscentrična pozicionalnost dovodi čovjeka do pojma Boga i napose do sumnje u njegovu egzistenciju, što ukazuje na svojevrsno Plessnerovo zapadanje u metafizičku skepsu. ${ }^{16}$ Sve to skupa nekako, makar i indirektno, uvelike izaziva pa i zahtijeva teološku refleksiju, bez obzira čini li se to nekome opravdanim ili neopravdanim.

Poradi svega toga, a i spomenutih mogućih poteškoća u pogledu teoloških interpretacija i teško odoljive izazovnosti Plessnerova koncepta, moguće je primijetiti dvostruke reakcije. $\mathrm{S}$ jedne strane postoje pokušaji teoloških interpretacija Plessnerova određenja čovjeka kategorijom ekscentričnosti u smislu pozitivnoga vrednovanja za daljnje teološke izvode. Tako, primjerice, suvremeni njemački katolički teolog Andreas Benk ističe važnost Plessnerove filozofske antropologije za teološku etiku. ${ }^{17} \mathrm{Na}$ tom tragu je zasigurno i Pannenbergov pristup dostignućima ne samo Plessnerove kategorije ekscentrične pozicionalnosti nego i čitave filozofske antropologije s početka prošloga stoljeća. ${ }^{18} \mathrm{Me}-$ đutim, neki teolozi smatraju da je kod ove vrste filozofske antropologije kakva

${ }^{14}$ Ovdje poglavito treba spomenuti njegovo djelo Stupnjevi organskoga i čovjek (Stufen des Organischen und Mensch) iz 1928. godine, ali i knjige Smijeh i plač (Lachen und Weinen) iz 1941. godine i Pitanje o conditio humana (Die Frage nach der Conditio humana) iz 1961. godine kao temeljne spise njegova filozofsko-antropološkoga promišljanja.

${ }^{15}$ Usp. Joachim FISCHER, »Mann ohne Eigenschaften«, »sozial relativ freischwebender Intelektueller«, »exzentrische Positionalität«. Musil, Mannheim, Plessner, u: Ulrich BRÖCKLING i dr. (ur.), Vernunft - Entwicklung - Leben. Schlüsselbegriffe der Moderne. Festschrift für Wolfgang Eßbach, München, Fink, 2004, 59-72, 69.

${ }^{16}$ Usp. Helmuth PLESSNER, Stupnjevi organskoga i čovjek, Zagreb, Naklada Breza, 2004, 306310.

${ }^{17}$ Usp. Andreas BENK, Skeptische Anthropologie und Ethik. Die philosophische Anthropologie Helmuth Plessners und ihre Bedeutung für die theologische Ethik, Frankfurt am Main, Peter Lang, 1987.

${ }^{18}$ Pannenberg u ovom kontekstu ističe da teološko kritičko prisvajanje neteoloških antropoloških istraživanja ne treba poistovjetiti s pukim nadovezivanjem (Anknüpfung) teologije na samorazumijevanje čovjeka, kako je od kraja 1920-ih godina bilo zahtijevano, primjerice teološkomisionarskim pristupom švicarskog teologa Emila Brunnera, kojem se u tom smislu u potpunosti suprotstavio drugi veliki evangelički teolog i njegov sunarodnjak Karl Barth (usp. Pannenberg, Anthropologie in theologischer Perspektive..., 19). 
je i kod Plessnera, zapravo riječ o svojevrsnom neprijateljskom raspoloženju prema teološkoj misli. Zbog toga i smatraju da se kritičko vrednovanje njezinih rezultata ne može drugačije niti zamisliti negoli jasnim isticanjem kršćanskih teoloških stavova njima nasuprot. ${ }^{19}$ Ipak takvi stavovi u teološkim su krugovima rijetkost jer zasigurno nisu $u$ duhu pozitivnoga vrednovanja rezultata filozofskih i znanstvenih istraživanja, kao ni dobronamjernih pokušaja njihove teološke recepcije općenito.

\subsection{Pannenbergova recepcija kategorije ekscentričnosti}

Prije negoli se prijeđe na Pannenbergovo tumačenje kategorije ekscentrične pozicionalnosti čovjeka, valja ukratko podsjetiti na to što je njemački filozof Helmuth Plessner tom kategorijom nastojao pojasniti. ${ }^{20}$ Naime, pojmom ekscentričnosti Plessner je označio fenomen čovjekove posebnosti unutar evolucije živoga. Ekscentrična bit čovjeka je, dakle, modifikacija jednog života kojeg dijele i životinja i čovjek, a specifičnost potonjeg jest u izdizanju iznad svijeta prirode te istodobno i u ostajanju dijelom toga svijeta, odnosno zarobljenim u njemu. U drugoj svojoj znamenitoj studiji će Plessner ustvrditi da je kod čovjeka riječ o biću koje je postavljeno između životinje i anđela, o životinji koja napušta životinjstvo. ${ }^{21}$

Osim toga, čovjeka, nasuprot životinji, odlikuje i sposobnost samorefleksije koja se izriče pojmom ekscentričnosti. Ta ga sposobnost vodi do odmaka, kako prema svemu što susreće tako i prema samom sebi, uključujući i njegovo vlastito tijelo. Po ekscentričnosti je čovjeku omogućena otvorenost svijetu, ali ne u Schelerovu neograničenom nego ograničenom smislu, što onda implicira već spomenutu unutarnju čovjekovu razapetost.

U svome djelu iz 1983. godine pod nazivom Antropologija u teološkoj perspektivi Pannenberg je preuzeo ovo razumijevanje bitne strukture čovjeka te, nadovezujući se na Plessnera, smatra da čovjekovoj biti doista pripada ekscentrično postojanje. Međutim, on stavlja i drugi naglasak kada tu čovjekovu specifičnost tumači kao izraz njegove religiozne naravi. Čovjek posjeduje svoj centar negdje izvan sebe, pa odatle onda samoga sebe i prihvaća i nadilazi, te se

\footnotetext{
${ }^{19} \mathrm{U}$ ovom kontekstu negativnoga raspoloženja općenito prema bilo kakvim mogućnostima prirodnog puta Božjega otkrivanje (theologia naturalis), a što implicira i odbacivanje mogućnosti nadovezivanja (Anknüpfung) na rezultate filozofskog i znanstvenog istraživanja o čovjeku, kao primjer se može ukazati na velikog evangeličkog teologa Karla Bartha (usp. Freimut SCHIRRMACHER, Der natürliche Mensch. Helmuth Plessners religionsanthropologische Systematik in ihrer Bedeutung für die theologisch-anthropologische Urteilsbildung, Würzburg, Königsheusen \& Neumann, 2000, 68).

${ }^{20}$ Podrobnije o tome vidjeti Ivo DŽINIĆ, Ekscentrična pozicionalnost u filozofskoj antropologiji Helmutha Plessnera, Nova prisutnost, 14 (2016) 3, 395-407.

${ }^{21}$ Usp. Helmuth PLESSNER, Condicio humana. Filozofijske rasprave o antropologiji, Zagreb, Nakladni zavod Globus, 1994, 105.
} 
povezuje sa stvarnošću izvan vlastitoga sebstva i izvan svijeta, te u konačnici sa stvarnošću samoga Boga.

Da bi pojasnio naznačenu ekscentričnu strukturu čovjeka Pannenberg poseže za općenitom ljudskom razumskom djelatnošću svakodnevne spoznaje pojedinačnih predmeta. Da bi se neki predmet mogao spoznati kao sasvim konkretan i točno određen, mora ga se moći i razlikovati ili razgraničiti od svih drugih predmeta, a takvo povlačenje granice već implicira i njezino nadilaženje. $^{22}$ To, prema Pannenbergu, vrijedi za iskustvo svakog konačnog sadržaja, odnosno iskustvo i spoznaja konačnoga kao konačnoga implicira odnos s beskonačnim. ${ }^{23} \mathrm{Na}$ taj način je čovjek u svojim pojedinačnim iskustvima uvijek vezan na sveopći i beskonačni horizont ili na sveukupnost (Gesamtheit), te mu samo unutar nje bivaju omogućena pojedinačna iskustva, spoznaje, značenja, pri čemu se ni u kojem slučaju ne misli na puku ideju ili predodžbu, nego na stvarnost te sveukupnosti. U tom smislu nastavlja Pannenberg svoje izvode:

»U prodoru na najopćenitiji horizont koji obuhvaća sve pojedinosti činjeničnoga i mogućega zapažanja (...) čovjek se ponaša ekscentrično prema stvarnosti koja mu je dana unaprijed i odatle je u tom prodoru implicitno supotvrđena božanska stvarnost, čak i ako kao takva već nije bila tematski obuhvaćena u ovoj ili onoj posebnoj formi. ${ }^{24}$

Čovjekova ekscentričnost dakle već implicira stvaran odnos s Bogom, premda čovjek o njemu još eksplicitno i ne mora znati, upravo zato što je taj odnos posredovan kroz konačne predmete i povijesne događaje, ali si ga tijekom života može osvijestiti.

Riječ je, dakle, o određenosti svake čovjekove svjesnosti o predmetima, kojom Pannenberg shvaća čovjeka kao biće vezano uz Boga. Budući da »predmet kada je shvaćen kao točno određen, jest već nadiđen, budući da određenost pojedinog predmeta biva shvaćena samo u beskonačno smislenom horizontu«, čovjek, prema Pannenbergu, kada se »priklanja jednom određenom predmetu« (...) oduvijek ga je već zahvatio preko svega konačnoga; jer samo u sklopu cjeline postaje nam moguće odrediti značenje pojedinačnoga. I Pannenberg nastavlja:

»Kad postanemo svjesni toga da mi u svakom obraćanju prema pojedinačnom, određenom predmetu, već jesmo zahvatili nad svim određenim, odnosno iznad ograničenoga i konačnoga, onda stojimo pred religioznom tematikom i time pred pitanjem o temeljnom povjerenju (Grundvertrauen), koje nosi naš život. Što eksplicitno može biti predmetom religiozne svijesti, implicitno je već u igri u svakoj pozornosti prema određenom predmetu našeg instinkta. « ${ }^{25}$

\footnotetext{
${ }^{22}$ Usp. Pannenberg, Anthropologie in theologischer Perspektive..., 65.

${ }^{23}$ Ovdje se može prepoznati svojevrsni kartezijanski inspiriran dokaz o Bogu i slaganje s Descartesom koji je u trećoj među svojim meditacijama nastojao pokazati da je spoznaja konačnoga kao konačnoga moguća samo pod uvjetom egzistencije Božje (usp. Langenfeld, Lerch, Theologische Anthropologie..., 81).

${ }^{24}$ Pannenberg, Anthropologie in theologischer Perspektive..., 66.

${ }^{25}$ Isto, 69.
} 
Na taj način Pannenberg u okvire svoje teološke antropologije ugrađuje spoznaje znanstvene filozofske antropologije. Istovremeno striktno odbija biološki redukcionizam i pokušava pribaviti dokaze čovjekove nužne vezanosti na Boga. ${ }^{26}$

Tako Pannenberg na temelju Plessnerovih izvoda kreće novim pravcem, tvrdeći da se ekscentrično ponašanje ne može pojasniti polazeći od čovjekove vlastite subjektivnosti ili slobode, nego isključivo od religioznoga cilja njegove povezanosti s Bogom. ${ }^{27}$ Međutim, valja istaknuti i da Pannenberg tu povezanost $\mathrm{s}$ Bogom ne želi temeljiti na tezi o Bogu kao ideji ili predodžbi koja je stvorena poradi potrebe za odgovorom na pitanje smisla čovjeka, pri čemu bi onda filozofski prije svega trebalo ostati otvoreno pitanje da li Bog uopće egzistira. Pannenberg obrće tezu i tvrdi da je povezanost s Bogom oduvijek već neiskazivo prisutna u ljudskom samoiskustvu i iskustvu svijeta. Čovjek je tom povezanošću prožet i prije negoli se shvati i ostvari kao reflektirajuće, slobodno i djelujuće bića. ${ }^{28}$ To znači da nije čovjek onaj koji poradi svojih potreba bilo koje naravi stvara ideju Boga, nego je stvarno postojeći Bog u čovjeka usadio njegovu čežnju za vlastitim ispunjenjem upravo u samome Bogu.

\subsection{Fenomen povjerenja kao antropološka datost}

Nastojeći dalje ponuditi argumente kojima utemeljuje čovjekovu povezanost s Bogom, Pannenberg poseže za rezultatima psihoanalize koja, između ostaloga, ukazuje na fenomen temeljnoga i izvornoga čovjekova povjerenja. ${ }^{29}$ Želi li se istražiti kakvu ulogu povjerenje ima u teologiji Wolfharta Pannenberga, onda postaje jasnim da je njemu na poseban način stalo do toga da temelj tog fenomena predoči kao antropološku datost. Da bi za to pronašao plauzibilne argumente Pannenberg se poziva na strukturalno bitno određenje čovjeka kao ekscentričnoga bića. Iz toga ne izvodi samo beskonačnu upućenost nego i čovjekovu nužnost da se pouzdaje.

Fenomen povjerenja je za čovjeka, prema Pannenbergu, pogotovo u njegovoj najranijoj dobi dojenja koliko nužan toliko i po sebi razumljiv. Budući da je čovjeku u toj životnoj fazi pristup i svijetu i sebi isključivo posredovan simbiozom s majkom, ne razlikujući ga od nje i pronalazeći ga upravo u njoj, taj fenomen je po sebi razumljiv. A nužnim se pokazuje iz razloga što je djetetu u vremenu sazrijevanja (heranreifendes Kind) bez tog izvornog povjerenja teško, ako ne i nemoguće, ophoditi se s negativnim iskustvima, razočaranjima i trpljenjima.

\footnotetext{
${ }^{26}$ Usp. Striet, Verdankte Autonomie..., 137-138.

${ }^{27}$ Usp. Langenfeld, Lerch, Theologische Anthropologie..., 81.

${ }^{28}$ Usp. isto, 82.

${ }^{29}$ Usp. Pannenberg, Anthropologie in theologischer Perspektive..., 222 i dalje.
} 
Tipičnost Pannenbergove argumentacije je u prikazivanju religiozne dimenzije na specifičnoj strukturi fenomena povjerenja. ${ }^{30}$ Povjerenje, po njemu, strukturalno uključuje neograničenost, beskrajnost, jer se usmjerava prema određenoj instanci, odnosno u navedenom slučaju prema majci, koja bez ograničenja potvrđuje i nosi konkretnog pojedinca u njegovu sebstvu (Selbstsein) tako da u potpunosti može biti i(li) postati što jest. Time se, pak, implicitno prekoračuju granice majčinih sposobnosti ili mogućnosti. Beskrajnosti temeljnog povjerenja, koja preko majke kao prvotnoga oblika njegova predmeta, ukazuje na Boga, odgovara njegova vezanost na cjelovitost sebstva (Selbst). Temeljno povjerenje se u svojem istinskom smislu usmjerava na onu instancu, koja to sebstvo u njegovoj cjelovitosti uspijeva potvrditi i poticati. Zato u življenje temeljnoga povjerenja najtješnje pripadaju Bog i spasenje. ${ }^{31}$

\section{Kritike Pannenbergove teološke recepcije kategorije ekscentričnosti}

Na obuhvatno Pannenbergovo prihvaćanje i uvažavanje dosega i rezultata filozofske antropologije nadovezivale su se i brojne kritike, koje više ili manje mogu i biti opravdane, ali zasigurno ne umanjuju vrijednost njegova nesumnjivo filozofski relevantnog i teološki kvalitetno argumentiranog pokušaja. ${ }^{32}$ Pannenbergu se, između ostaloga, zamjera što je njegova recepcija Plessnerovih antropoloških postulata uglavnom određena vlastitom teološkom hermeneutikom, koja specifično usmjerenje filozofske antropologije s početka prošloga stoljeća gleda propedeutski usmjerenom prema sebi, ističući da rodoslovlje (Stammbaum) moderne antropologije upućuje nazad na kršćansku teologiju i da je znakovito da na njezinim početcima stoji jedan teolog, odnosno Johann Gottfried Herder. ${ }^{33} \mathrm{U}$ tom kontekstu se kritički ističe da se teško može govoriti o eventualnoj interdisciplinarnosti i svojevrsnom susretu filozofije i teologije u pokušaju dokučivanja čovjeka, nego više o podređujućem razumijevanju filozofsko-antropoloških dosega i isključivoj teološkoj relevantnosti da odgovori na sve ono na što prva ne uspijeva. S ovom kritikom usko je povezano i Pannenbergovo ukazivanje na deficitarnost novovjekih humanističkih znanosti u odnosu na teološku univerzalnost, smatrajući da druge znanosti tematiziraju samo djelomične aspekte ljudske stvarnosti i da na tragu sekulariziranog duha vremena zapostavljaju čovjekove duboke religiozne dimenzije. Kritičari takvog

\footnotetext{
${ }^{30}$ Usp. Langenfeld, Lerch, Theologische Anthropologie..., 79.

${ }^{31}$ Usp. Pannenberg, Anthropologie in theologischer Perspektive..., 227.

${ }^{32}$ Ovaj dio teksta o kritičkim točkama Pannenbergova pokušaja teološke interpretacije rezultata filozofske antropologije i posebice kategorije ekscentrične pozicionalnosti temelji se na: Andrea LASSAK, Grundloses Vertrauen, Tübingen, Mohr Siebeck, 2015, 60-63 i Schirrmacher, Der natürliche Mensch..., 69.

${ }^{33}$ Usp. Pannenberg, Was ist der Mensch?..., 12.
} 
Pannenbergova pristupa smatraju da se i time uvelike potkopava možebitna platforma za znanstvenu interdisciplinarnost, jer se nastoji bitno suziti perspektiva (filozofsko) antropološkog pristupa i gledati isključivo vlastite znanstvene (teološke) interese.

Daljnja kritika Pannenbergove teološke interpretacije Plessnerovih osnovnih antropoloških postulata odnosi se na njihovu integraciju u njegov teološki argumentacijski okvir i to bez značajnijih ograničenja. Kritički se to tumači kao neprimjereno vrednovanje Plessnerove filozofske originalnosti unutar antropološko-istraživačkog rada. Kao primjer se u ovom kontekstu navodi da Pannenberg pretvara Plessnerov postulat čovjekove ekscentrične zadanosti u svojevrsnu određenost za ekscentričnost. Prisvajajući Plessnerovu karakterizaciju čovjeka kao ekscentrično pozicioniranog bića, Pannenberg ujedno i rastavlja kategoriju ekscentrične pozicionalnosti i osamostaljuje elemente ekscentričnosti i pozicionalnosti (centriranosti). To se zaključuje na temelju Pannenbergove tvrdnje da

»čovjek ostaje ekscentričan, vezan uz nešto drugo izvan njega samoga, ali sada na nešto Drugo s onu stranu svih predmeta njegova svijeta, koje istovremeno obuhvaća taj cijeli svijet i tako čovjeku jamči moguće jedinstvo njegova ispunjenja života u tom svijetu, unatoč manjkavosti i heterogenosti njegova utjecaja«., ${ }^{34}$

Kritika Pannenbergu je u ovom kontekstu usmjerena prema neposrednom postavljanju Boga za ekscentrični čovjekov centar, a time i potkopavanje Plessnerove izvorne ideje. Naime kada Plessner ukazuje na pojmove religije, religioznosti i Boga, uglavnom ih koristi u smislu čovjekove potrebe, promišljanja ili (samo)propitkivanja, te naznačuje da njegova ekscentrična pozicioniranost ne uspijeva shvatiti zbilju koja bi joj odgovarala, poradi čega čovjek može posegnuti za vjerom..$^{35}$ Tako Plessner zapravo i ograničava vlastite istraživačke mogućnosti i priznaje da je na sva daljnja pitanja nemoguće više odgovoriti antropološkim sredstvima nego eventualno svojevrsnim skokom u vjeru.

Sve ove kritičke opaske jasno aludiraju na različitosti između Plessnerovih neteoloških antropoloških obrazaca i Pannenbergove teološke recepcije i interpretacije, kao i na zaključak da Pannenberg Plessnerove antropološke postulate zapravo reinterpretira ili čak krivo interpretira. Doista ovakve kritike donekle mogu biti i opravdane. Naime već su u gornjem tekstu navedene moguće poteškoće vezane općenito za interpretacije znanstveno-humanističkih i pogotovo filozofsko-antropoloških dosega, pogotovo u pogledu eventualnih negativnih učinaka i zasjenjivanja kako općenite otvorenosti takvih dosega tako i kompleksnosti suvremenog čovjekova samoiskustva i iskustva svijeta.

\footnotetext{
${ }^{34}$ Pannenberg, Anthropologie in theologischer Perspektive..., 66.

${ }^{35}$ Vidjeti o tome napose elaboriranje Plessnerova trećeg antropologijskog zakona, onog o utopijskom stajalištu, u kojem kao bitni motivi za razumijevanje čovjeka dominiraju upravo ništavost i transcendencija, u: Plessner, Stupnjevi organskoga i čovjek..., 306-310.
} 
Međutim, iako u ovom tekstu nije cilj braniti (niti opovrgavati!) Pannenbergove teze, autoru ovih redaka se čini opravdanim ustvrditi da Pannenbergov pokušaj nije bio negativno nastrojen, odnosno omalovažavajući i pogotovo ne relativizirajući, nego je više proizišao iz vlastitoga kako subjektivnog tako i intelektualnog i stručnog raspoloženja, u nastojanju da izgradi svoje izvode uvažavanjem kvalitetnih misaonih dosega koji po sebi čine ne samo relevantno nego i primjereno tlo za to. Jer, kako je već više puta istaknuto, neki Plessnerovi postulati i konkretni izvodi, kako poradi opće tematike pokušaja razumijevanja čovjeka, tako i poradi neizbježnog zadiranja u metafizičko područje, jednostavno izazivaju teološku interpretaciju.

Činjenica jest da je Plessner općenito religioznu dimenziju protumačio kao čovjeku imanentnu stvarnost koja nema veze s transcendencijom, to zasigurno ne znači da se ne smije dalje promišljati upravo u tom pravcu. U konačnici sâm eventualni "skok u vjeru«, na kojeg i on ukazuje, zasigurno ničim ne ugrožava njegovu filozofsku originalnost i lucidnost nego je, štoviše, duboko uvažava i izdiže na područje transcendentalne relevantnosti. Upravo negiranje toga bi bilo protiv otvorenosti znanstvenih i pogotovo filozofskih dosega, a što se kao kritika upućuje upravo Pannenbergovu pristupu. Osim toga, uvažavanjem rezultata filozofske antropologije u svojem teološkom pristupu čovjeku Pannenberg pokazuje visoku razinu poštovanja prema neteološkim znanostima.

To je važno istaknuti zato što se ovog teologa nerijetko kritiziralo upravo radi nedovoljnog vrednovanja neteoloških znanosti, iz čega jasno proizlazi koliko i kritike mogu biti plod osobne interpretacije, a ne širine znanstvenoga sagledavanja. Stoga se njegov pokušaj približavanja teologije drugim neteološkim humanističkim znanostima, napose filozofskoj antropologiji, može interpretirati i kao paradigmatski okvir za znanstvenu interdisciplinarnost, a ne kao ono što tu interdisciplinarnost potkopava. U konačnici, upravo je teologija u novije vrijeme nerijetko uopće malo vrednovana kada je riječ o eventualnoj interdisciplinarnosti, ne samo radi njezinog specifičnog materijalnog i formalnog objekta znanstvenog istraživanja, koji istina polazi od postojanja nečega apsolutnoga (nekoga Apsolutnoga), a samim tim i univerzalnoga, nego upravo i radi toga što se iz takvog (ne)vrednovanja teoloških postulata zazire od mogućeg transcendentalnoga aspekta ljudske religioznosti.

\section{Zaključak}

Filozofska antropologija s početka 20. stoljeća je specifičan i zanimljiv pokušaj razumijevanja čovjeka, te su kategorije koje se odnose na čovjeka, proizašle iz tog pokušaja, danas postale nezaobilaznim dijelom cjelokupnog filozofsko-antropološkog rječnika. Osim te specifičnosti i zanimljivosti, taj pokušaj znanstveno (biologijski) utemeljene filozofske antropologije, koji ukazuje 
na čovjekovu prirodnost te istodobno na natprirodnost, njegovu otvorenosti svijetu i ekscentričnost $u$ odnosu na druge sfere organskoga, upravo tim svojim karakterizacijama postaje i zanimljiv izazov za teološke interpretacije. Taj je izazov prihvatio i Wolfhart Pannenberg koji je kao teolog možda i ponajviše bio vođen uvažavanjem i teološkoga diskursa u suvremenom svijetu, napose teološko-kritičkim vrednovanjem rezultata suvremene antropologije. Prihvaćajući i teološki vrednujući rezultate istraživanja cjelokupne filozofske antropologije s početka 20. stoljeća, a napose Plessnerove karakterizacije čovjeka kao ekscentrično pozicioniranog životnog oblika, Pannenberg je pokazao, prije svega, dobro razumijevanje dotične filozofije, ali i odvažnost i originalnost $u$ teološkoj interpretaciji njezinih rezultata. $S$ teološkog motrišta riječ je o hvalevrijednom pokušaju koji želi osuvremeniti i teološki diskurs te ga aktualizirati i (iznova) predstaviti relevantnim u novim kulturološkim okolnostima. Takav pokušaj iziskuje, prije svega, veliku širinu znanja i upućenosti u dosege novije filozofsko-antropološke misli, kao i sposobnost njihova primjerenog teološkog vrednovanja.

Ovaj prikaz te Pannenbergove recepcije temeljnih filozofsko-antropoloških određenja čovjeka, bilo kroz kategoriju čovjekove otvorenosti svijetu ili ekscentrične pozicionalnosti u svijetu, pokazao je logički uređen misaoni sustav i smislenu teološku nadogradnju kojoj se $s$ tog čisto sadržajnog aspekta teško može naći zamjerke. Naime, nezadanost i nedeterminiranost tih karakterizacija čovjeka, ostavlja slobodu za mogućnost njihove teološke interpretacije. Bilo bi neozbiljno takve interpretacije a priori proglasiti nepoželjnima ili nemogućima, bez obzira da li naznačeni filozofski pokušaji eksplicitno zaziru upravo od takvih interpretacija. Oni ostaju na razini čovjekove nezadanosti i otvorenosti horizontima koje je teško dokučiti logičko-misaonim aparatom kojim raspolaže filozofska antropologija. I sam Plessner, kako je spomenuto, govori da je došao do granice preko koje je moguće iskoračiti jedino skokom u vjeru. Nije li već ta njegova konstatacija, kao i način na koji načinje i interpretira i druge teme, napose karakteristične za metafizičko i teološko područje, nešto što ne samo nudi mogućnost nego i izaziva na pokušaj daljnjeg teološkog interpretiranja i nadogradnje? Pannenberg je tom izazovu odgovorio na najbolji mogući način, uvelike uvažavajući rezultate znanstvenih dosega, ali i njihove ograničene mogućnosti u odnosu na teološku otvorenost prema transcendentnome, što ni u kojem pogledu ne treba tumačiti kao podcjenjivanje i omalovažavanje filozofskih i znanstvenih misaonih mogućnosti. 


\section{Ivo Džinić* \\ Category of Eccentric Positionality in Theological Perspective: \\ Wolfhart Pannenberg and Helmuth Plessner \\ Summary}

This paper focuses on an attempt of understanding of a man as a characteristic of a philosophical anthropology at the beginning of the $20^{\text {th }}$ century. In particular, it refers, to the category of eccentric position of a man in relation to the other forms of life as formulated by Helmuth Plessner, one of the main representatives of this type of philosophical anthropology. The principal argument of the article is a perception of theological interpretation of Plessner's category of man's eccentricity by the evangelical theologian Wolfhart Pannenberg. Positively evaluating and accepting Plessner's philosophical-anthropological postulates, Pannenberg sought to expand them much further in the theological perspective, thus endeavouring to demonstrate the necessity of acceptance of religious dimension in characteristics and, generally accepted, anthropological phenomena. The paper attempt to show the measure in which these types of theological interpretations are desirable and possible. Also, it appoints to some critical remarks regarding Pannenberg's attempt of theological approach to the results of a strictly philosophical anthropology.

Key words: anthropology, eccentricity, philosophy, openness to the world, theology, trust.

(na engl. prev. Ivo Džinić)

\footnotetext{
* Ivo Džinić, PhD, Assoc. Prof., University of Zagreb, Department of Croatian Studies; Address: Borongajska cesta 83d, HR-10000 Zagreb, Croatia; E-mail: idzinic@hrstud.hr.
} 